\title{
重畺M波解析による疲労に伴う表面筋電図徐波化機構
}

\author{
山田 洋 ${ }^{1}$ 木塚朝 博 ${ }^{2}$ 増田 正 $^{1)}$ 横井孝志 ${ }^{1}$ \\ 金子文成 ${ }^{1)}$ 金子公宏 ${ }^{3)}$ 岡田守颜
}

\section{MECHANISM FOR SLOWING SURFACE ELECTROMYOGRAPHY DURING FATIGUING CONTRACTION REVEALED BY SUPERIMPOSED M-WAVE ANALYSIS}

\author{
Hiroshi Yamada, Tomohiro Kizuka, Tadashi Masuda, Takashi Yokol, Fuminari Kaneko \\ KimiHIRO KaNEKO and MORIHOKO OKADA
}

\begin{abstract}
We studied the mechanism for slowing surface electromyography (EMG) during fatiguing contraction using superimposed $\mathrm{M}$-wave analysis. Seven healthy male subjects exerted $60 \%$ maximum voluntary contraction of isometric abductions in the left first dorsal interosseous muscle (FDI) until exhaustion. Simultaneously with voluntary contractions, the ulnar nerve was electrically stimulated at supramaximal intensity, and volitional EMG and superimposed $\mathrm{M}$-waves were obtained. We examined the behavior of muscle fiber conduction velocity (MFCV) and median frequency (MDF) for both EMG, with the following results :

1) $\mathrm{MFCV}$ calculated from volitional EMG of FDI was about $6 \mathrm{~m} / \mathrm{s}$ during $60 \% \mathrm{MVC}$.

2) The waveform of voluntary EMG detected from FDI slowed in all subjects during fatiguing contraction at $60 \% \mathrm{MVC}$, indicating fatigue had developed in the muscle.

3) As fatigue progressed, the waveform of the superimposed $M$-wave tended to decrease in anplitude and increase in duration.

4) As fatigue progressed, MDF and MFCV in volitional EMG decreased significantly $(\mathrm{p}<0.01)$ The rate of change was larger in MDF than in $M F C V(p<0.01)$.

5) As fatigue progressed, MDF and MFCV in the superimposed M-wave decreased significantly $(\mathrm{p}<0.01)$. The rate of change was larger in MDF than in MFCV $(p<0.05)$.

These results suggested that MFCV and other peripheral factors affected the slowing of voli. tional EMG. Elongation of the depolarization zone in muscle fiber is proposed as a peripheral factor.

(Jpn. J. Phys. Fitness Sports Med. 2003, $52: 29 \sim 42$ )

key word : muscle fiber conduction velocity, median frequency, FDI, maximum voluntary contraction
\end{abstract}

\section{I . 緒}

言

非侵襲的な筋疲労の評価法として, 表面筋電四 法が従来広く用いら机て抢り, 疲労進行に伴い,

1）筋電図積分值の増大，扩よび 2) 徐波化(周
波数の低域シフト)が生ずることがよく知られて いる ${ }^{1 \sim 4)}$ 。前者は試行差，筋差等の変動が大き いが，後者は比較的安定した結果を得ることがで きることから，筋疲労の評価法としてほぼ確立し つつあり, 中央周波数 (Median Frequency : MDF)

1)産業技術総合研究所人間福祉智工学研究部鬥 National Institute of Bioscience and HumanTechnology Higashi 厂305-8566 つくば市束1-1-1

2) 筑波大学体育科学系 テ305-8576つくば車天キ:占1-1-1

3) 明治大学商学部 于 168-8555東京都杉並区永福町1-9-1

4) 筑波大学先端学際領域研究センター 下305-8577 つくば市天王台1-1-1 1-1-1, Tsukuba-shi, 305-8566 Institute of Health and Sport Sciences, University of Tsukuba Tennodai 1-1-1, Tsukuba-shi, 305-8576 Meiji university the department of commercial science part time lecturer Eifukucho1-9-1. Suginami-ku, 168-8555 Center for Tsukuba Advanced Research Alliance, University of Tsukuba Tennodai 1-1-1. Tsukuba-shi, 305-8577 
や平均周波数 (Mean Power Frequency : MPF) 等 の周波数特性值を用いた筋疲労モ二夕も考案され ている3).

この徐波化の機構については, 筋内 $\mathrm{pH}$ の低下 に基因する筋線維伝導速度 (Muscle Fiber Conduction Velocity：MFCV)の低下による運動単位活動 電位の shape 注) の変化が主因であることが, 多く の研究より明らかになっている ${ }^{5-7)}$. しかしな がら，実際はMFCVの低下よりも，MDFや $\mathrm{MPF}$ のような周波数特性值の低下のほうが大き いことが多い8.9).

この徐波化を生じさせる MFCV 低下以外の要 因の第 1 候補として，古くから筋内埋入電極や表 面筋電図を用いて, 運動単位の同期化, 運動単位 発射パターンの变化等の中枢性要因の関与が調べ られている1.2.10〜12). 低収縮・長時間収縮によ る疲労に伴い, 運動単位の発射頻度に対応した周 波数ピークが存在することも知られている7). し かしながら，これらは表面筋電四の波形自体に影 響を与えつつも，その周波数は $30 \mathrm{~Hz}$ 以下である こと，加えてそのパワー自体も小さいことから， 周波数特性値自体に与える影響は小さいとのみか たが強い13)。したがって, 徐波化を生じさせる MFCV 低下以外の要因についての議論の決着は, 未だついていない.

そこで我々は, 疲労に伴う表面筋電図の徐波化 に筋線維伝導速度低下以外の末梢性要因が関与す るという仮説を設定し，これをヒトにおいて実験 的に検証するために，誘発筋電図 (M波)に着目し た。誘発M波は，筋あるいは筋を支配する神経幹 を電気刺激することによって得られる複合活動電 位であり，中枢性の情報を含まない純粋な末梢の 指標である ${ }^{14)}$ 。したがって，この誘発M波につ いて，随意による表面筋電図変化と同様の結果が

注) shape は, 振幅および時間領域におけるスケール が不変の信号特性を意味し，この例として活動電 位の位相があげられる。これに対し, waveform は, 信劣や時間関数に関係する電流や電圧の伝搬 の総括的概念を意味し, shape や振幅, 持続時間 等をすべて含んでいる (Basmajian and De Luca, Muscles Alive, 1985)。 shape および waveform は いずれも波形(または波形形状) と訳すが，本論文 に抏いては，これらを区別して取り扱う。
得られれば，徐波化に対する末梢性要因の関与を 立証することができる。本研究は，MFCV 以外 の要因が表面筋電四の徐波化に関与するか否かを 検証するために, 筋疲労進行に伴う随意筋電位と それに重畳する誘発M波の MFCVとMDFの变 化動態を比較検討した。

\section{II. 方法}

\section{A. 被験者と実験設定}

被験者は T大学に所属する健康な男子学生 7 名 で, 年龄は21 29歳 (身長176.2 $25.5 \mathrm{~cm}$, 体重72.9 $\pm 6.0 \mathrm{~kg}$ ) であった。被験者にはあらかじめ実験 の趣旨を説明したうえで了承を得た。被験者は全 て右利きであった。実験は左手を対象として行っ た。

被験者を椅子に座らせ，手掌を回内した状態で プレートの上にのせ，示指の等尺性外転を行わせ た。等尺性外転のための負荷装置は手掌固定用板 と外転加重測定部分によって構成されている. 被 験者が外転力を加重板に加えるとロードセル (TEAC，TU-CR5K)に張力が加わる(図1 A). ロードセルの出力は動歪増幅器 (KYOWA, DPM-711B)を通じてオシロスコープにモニタし， 被験者に一定張力を維持させた。

同時に外部より尺骨神経を介した電気刺激を加 之，第一背側骨間筋(First Dorsal Interosseus : FDI）より表面筋電位を導出した（図１Ｂ）。なお， FDI は示指の掌屈筋としても作用するため, 外転 力を正確に計測できないという報告もなされてい $ろ^{15)}$. そこで本実験では, ストレインゲージ(共 和電業, LM-5KA) を用いて掌屈方向の張力も計 測し，随意収縮時，および電気刺激による収縮時 に掌屈方向への力が出ないように留意した。

\section{B. 電気刺激}

電気刺激には生体電気刺激装置 (日本光電, SEM-4201)を用い, 誘発筋電四用表面刺激バー電 極 (バーのサイズ $110 \mathrm{~mm} \times 32 \mathrm{~mm} \times 13 \mathrm{~mm}$, 電極 直径 $9 \mathrm{~mm}$, 電極間間隔 $18 \mathrm{~mm}$ )を时部に当て, 尺骨神経を経皮的に刺激した。刺激ポイントは安 静時に記録される単収縮力, M波の両者が最も大 

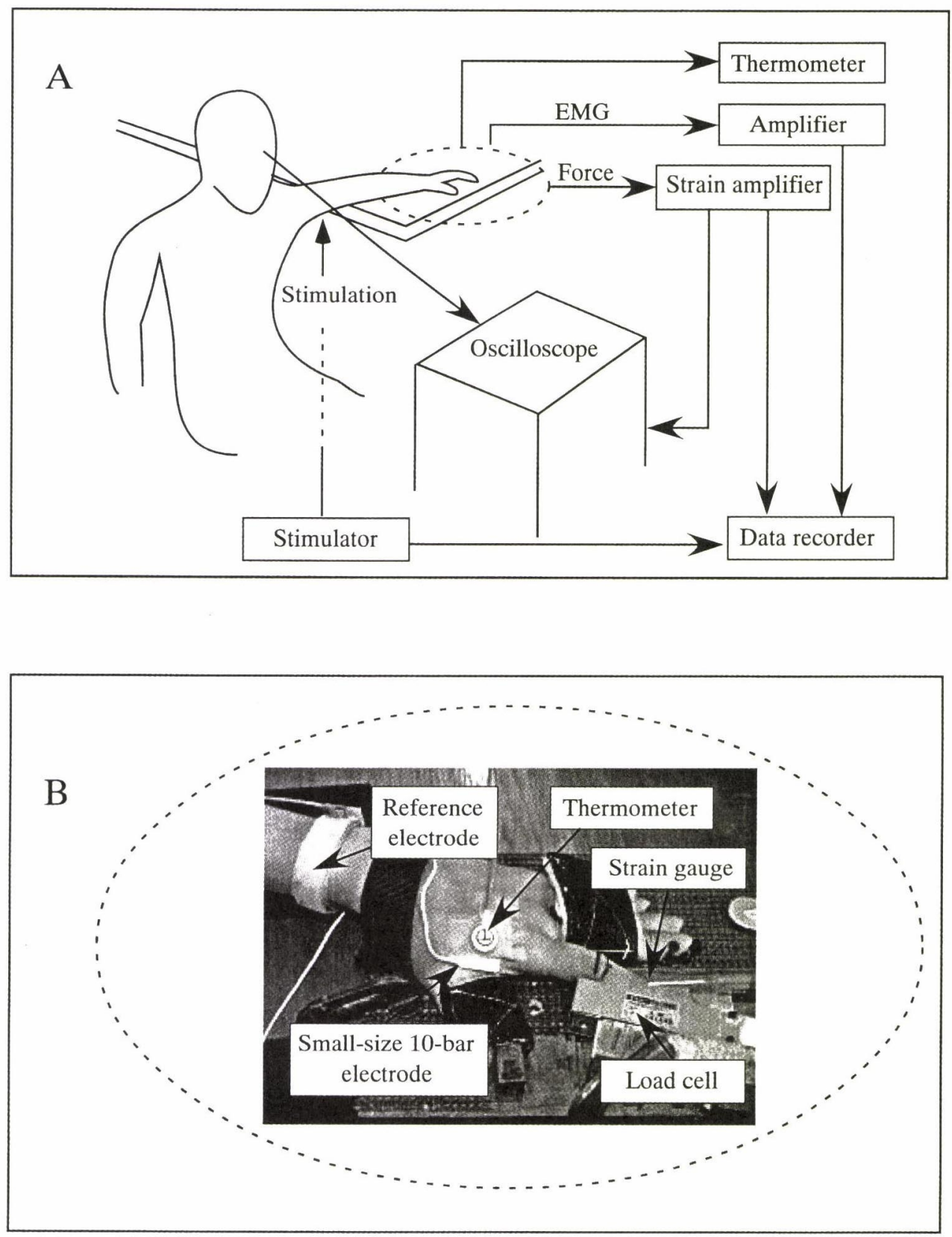

Fig. 1. Arrangement of pick-up electrode and thermometer (A). Experimental setup for recording muscular force, EMGs, and muscle temperature (B). Force regulation by visual feedback (C).

きく検出される部位とした。刺激は持続時間 0.1 msec の矩形波を単発で用い, 5 秒間隔で行った。

刺激強度は, $\mathrm{M}$ 波の振幅が変化しない最大上強度 を被験者毎に設定し，その值は70１40 V の範
囲にわたっていた。

C. プロトコール

各試技に先立ち, 被験者に約 3 秒間の最大随意 
収縮 (Maximum Voluntary Contraction:MVC)を 行わせ，発揮張力を測定した。第一指と示指のな す角度は60度とし，示指の基節中節関節にマーキ ングを施し，カセンサーの作用点にぴったり合う ように留意した。試技は 5 分間の休息をはさんで 2 回行った。

10分間の休息後, $60 \% \mathrm{MVC}$ 強度の等尺性外転 を行わせ，同時に肘部より経皮的に尺骨神経を刺 激した。疲労課題は, 被験者が発揮張力の目標レ ベルを維持できなくなるまで行わせ，臨界点 (Failure Point : FP)はターゲットのー10\%とし， 収縮開始から FP までの時間を持久時間 (Endurance Time : ET) とした。なお，各試技の 前後に安静時のM波および単収縮張力を記録し た。

\section{D. 記録方法}

これまで多点アレイ電極を用いた表面筋電図計
測は, 上腕二頭筋, 前脛骨筋, 外側広筋等の比較 的大きな筋には適用されているが16.17।，FDI で の報告はみられない。そこで今回，FDIにおける 筋電位導出には, 長さ $4 \mathrm{~mm}$ のステンレス線を $2.5 \mathrm{~mm}$ 間隔で配置した $7 \mathrm{~mm} \times 24 \mathrm{~mm} \times 3 \mathrm{~mm}$ の 小型10線多点電極(ユニークメディカル)を用い, 隣接した線より 9 チャンネルを差動導出した(図 $2 \mathrm{~A}$ ).

疲労実験に先立ち, 電極を筋線維走行と平行に 配置し，精度良く筋線維伝導速度および筋電図周 波数パラメー夕を計測するために, 導出電極位置 を決定するための実験を行った．被験者の FDI に電極を仮装着した後に $50 \% \mathrm{MVC}$ 強度の示指の 外転をさせ，Masuda ${ }^{18)}$ の開発したテレビモニ夕 を用いて多チャンネルで検出された筋電位の伝搬 を確認した。同時に, 得られた EMG をコンピュー 夕に取り込み, 各チャンネルについて相互相関係 数 (cross correlation coefficient : CC) を計算し,
A

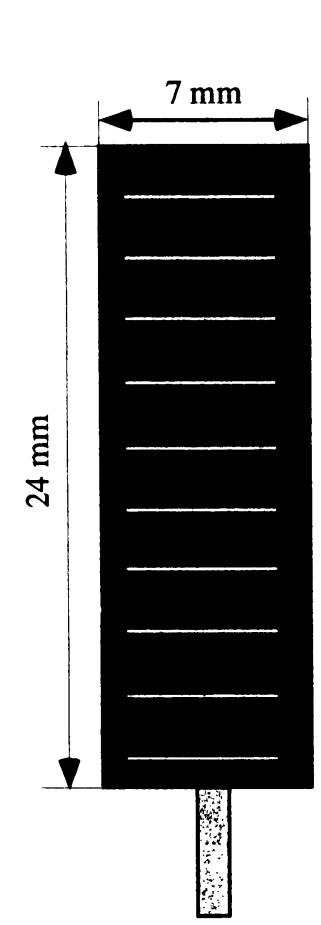

B
Stimulation

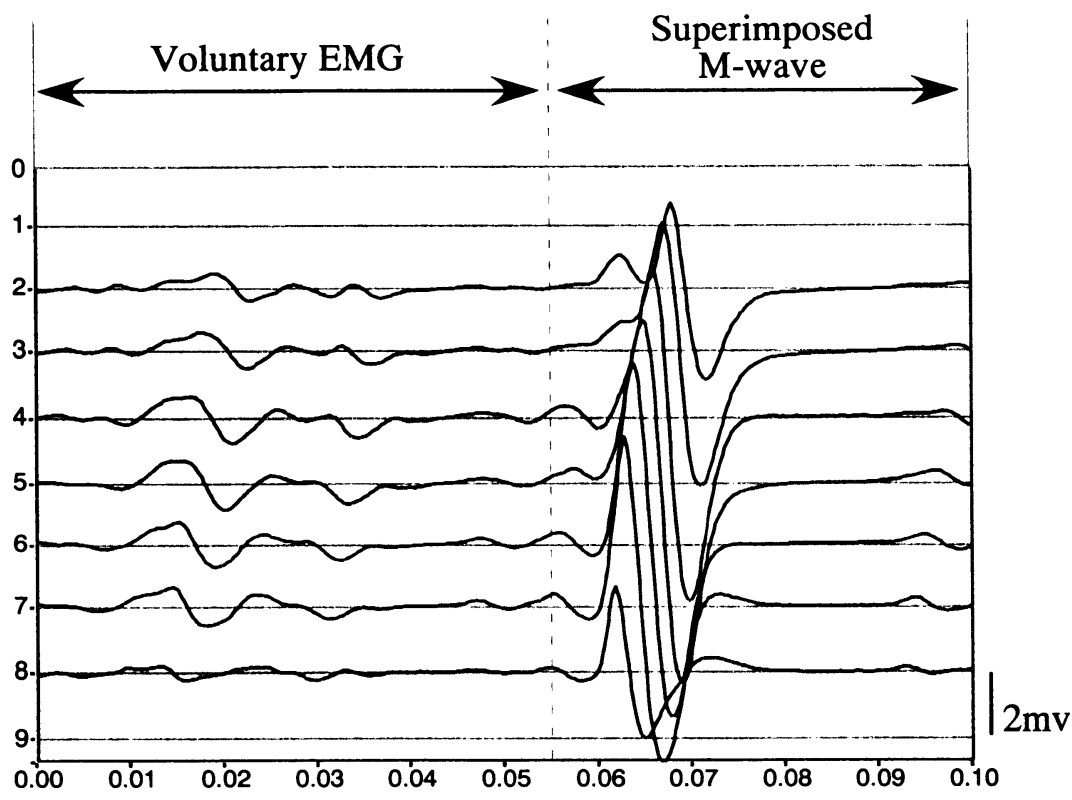

Proximal

Time (s)

Fig. 2. Voluntary EMGs and superimposed M-waves detected by small multi-channel electrode. The time shift was calculated form propagation pattern of EMGs. 
すべてのチャンネルで 0.8 以上の值が得られる部 位を検出部位として採用した。

得られた筋電位デー夕は時定数 0.03 秒, 高域遮 断周波数 $1 \mathrm{kHz}$ で増幅後, 電気刺激のトリガー 信号, 外転力, 掌屈力とともにデータレコーダ (SONY，PC208Ax)に収録した。被験筋の表面温 は温度計(テルモ,コアテンプ)によりモニタした。

\section{E．解析方法および統計処理}

収録したデータはサンプリング周波数 $10 \mathrm{kHz}$, 12 bit で A/D 変換した。このとき, 得られた 9 ch の EMG のうち，随意筋電位とそれに重畳し て出現するM波(以下，重畳M波とする)のそれぞ れについて，神経支配带の影響を受けずに明瞭な 伝播パターンと時間ずれが検出できる $7 \mathrm{ch}$ を選 択した(図 2 B)。なお，収縮開始直後は発揮張力 が安定しないために，疲労課題開始後，発揮張力 が目標レベルに達してからのデータを解析に用い た.

解析パラメータとして，随意筋電位掞よび重胃 M波の両者について中央周波数 (median frequency： MDF)を用い，以下の式によって算出した ${ }^{7,19}$.

$$
\int_{0}^{f m e d} P(f) d f=\int_{f m e d}^{\infty} P(f) d f
$$

ここで $\mathrm{P}(\mathrm{f})$ は，筋電位パワースペクトルを表 す.

また，筋線維伝導速度 (muscle fiber conduction velocity : MFCV)を以下の式によって算出した。

$\mathrm{MFCV}=\mathrm{D} / \mathrm{T}$
ここで Dは電極閪距離，Tは EMG の時間差を 表し，隣接する信忩のピーク間の時間差を求め た ${ }^{16.20 !}$.

重畳M波の波形解析区間は電気刺激トリガー後 $5 \mathrm{~ms}$ から $51.2 \mathrm{~ms}$ とし，十分な解析区間を得る ために zero padding を行い, $3276.8 \mathrm{~ms}$ の信号を 解析した ${ }^{21)}$ 。随意筋電位の解析区間は $8192 \mathrm{ms,}$ シフト長は $1 \mathrm{~s} と し ， 1$ 秒毎のデー夕を求めた。 なおM波やその記録に伴う基線の摇れ等を避ける ために，電父揦激のアーチファクトをトリガーと して，淔前の5秒間毎に值を算出した。

表面筋電図変数の算出には，CC が最も高く， 神経・筋接合部の影響をうけないチャンネルペア を選択した。一人の被験者について得られた筋 電四変数を 1 秒开にプロットし，回帰直線をもと め, 疲労前, 疲労後の值を算出した ${ }^{22,23)}$ 。統計 処理については対応のあるt-testを用い，有意 水準は $5 \%$ 末満とした。

\section{III. 結}

\section{果}

\section{A．表面筋電図変数の絶対値}

表 1 に $60 \% \mathrm{MVC}$ 波労試技前に, FDI で得られ た筋電位変数を示す.FDI の外転力は平均で 2.2

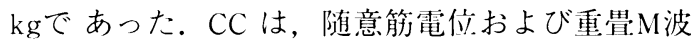
において0.9以上と高い值を示した.MDF の值は， 随意筋電位と比較して重畳M波で大きかった。こ 孔に対し，MFCV の值は，随意筋電位で大きかっ た。

B. 収縮持続に伴う筋電位の変化

$60 \% \mathrm{MVC}$ 強度の収縮課題における ET は 78.4

Table 1. Pre-fatigue EMG variables of voluntary EMG and $\mathrm{M}$-wave during $60 \%$ max . imum voluntary contraction. $\mathrm{CC}$ : cross correlation coefficient, MDF : median frequency, MFCV : muscle fiber conduction velocity

\begin{tabular}{lcc}
\hline Parameter & Voluntary EMG & Superimposed M-wave \\
\hline \hline CC & $0.96 \pm 0.01$ & $0.98 \pm 0.02$ \\
MDF $(\mathrm{Hz})$ & $102.91 \pm 31.83$ & $152.13 \pm 47.25$ \\
$\operatorname{MFCV~}(\mathrm{m} / \mathrm{s})$ & $5.99 \pm 1.83$ & $4.17 \pm 2.41$ \\
\hline
\end{tabular}



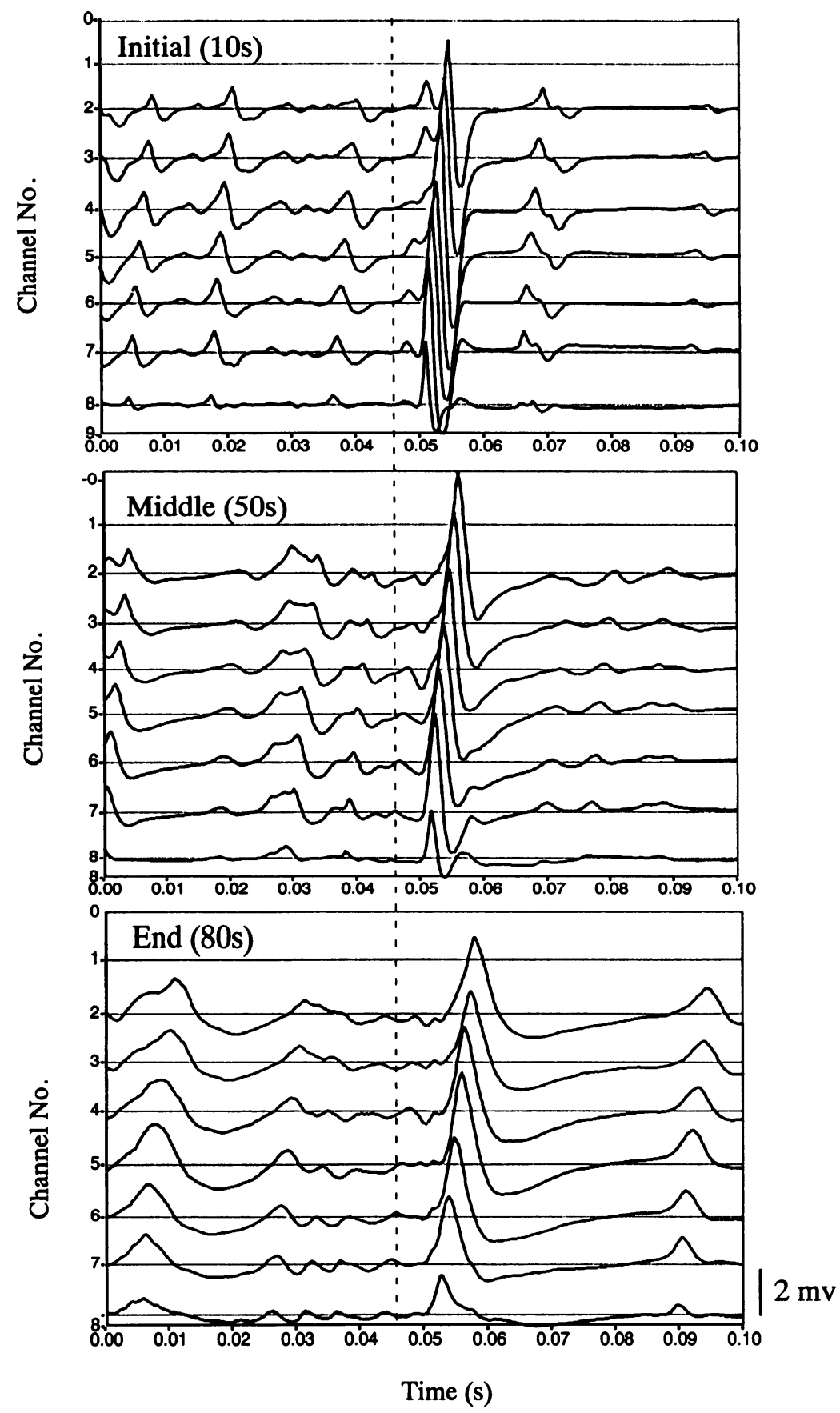

Fig. 3. Typical change of EMG waveform during $60 \% \mathrm{MVC}$ fatiguing contraction. Each EMG waveform was at beginning $(10 \mathrm{~s})$, middle $(50 \mathrm{~s})$, and end $(80 \mathrm{~s})$ of sustained abduction of index finger. Vertical dotted line denotes stimulation point. The slowing of voluntary EMG and superimposed $\mathrm{M}$-waves were seen with fatigue progression. 
士15.4秒であった。図 3 に収縮初期，中期掞よび 終期の随意筋電位㧍よび重宣 $\mathrm{M}$ 波の生波形の 一例 を示す，収縮持続に伴い，随意筋電位が徐波化す る様子がわかる，随意筋電位の振幅は一貫した变 化を示さなかった。一方，重畺M波の振幅が低下 し，持続時閒が延長する様了も想められる。これ らの結果は全被験者について共通して認められ た。

\section{C. 随意筋電位のMDFとMFCVの变化パ} ターン

図 4 に随意筋電位の MDF および MFCV の経 時変化を示す。縦軸は疲労試技に抢ける初期值を 100\%，横軸は ETを100\%としてそれぞれ基準化 し, 平均値土標準偏差で示した。随意筋電位の MDFと MFCVはともにほほ単調に減少した。 MDFの減少は, 初期值に対して 10\%ET から有 意となり，MFCV の減少は20\%ET から有意と
なった $(\mathrm{p}<0.05) . \mathrm{MDF} と \mathrm{MFCV}$ を比較すると， $\mathrm{MFCV} よ り \mathrm{MDF}$ で減少の幅が大きく, 20\%ET から 100\%ET 間において有意な差が認められた $(\mathrm{p}<0.05, \mathrm{p}<0.01)$.

\section{D. 重畳M波のMDF と MFCVの変化パター}

脳 5 に重胃M波の MDF および MFCV の経時 変化について, 四 4 と同様に示す。重畳M波の MDF, MFCV はともに減少し, 疲労の進行を示 していた. MDF, MFCV の減少は, 初期值に対 していずれも $10 \% \mathrm{ET}$ から有意となった $(\mathrm{p}<$ $0.05, \mathrm{p}<0.01)$. MDF と MFCV を比較すると, MDF でより大きく減少しており，30\%，80\%， 100\%ETに扔いて有意な差が認められた $(\mathrm{p}<$ 0.05). MDFと MFCVの減少幅は, 随意筋電位 に比べ，重胃M波で小さかった。

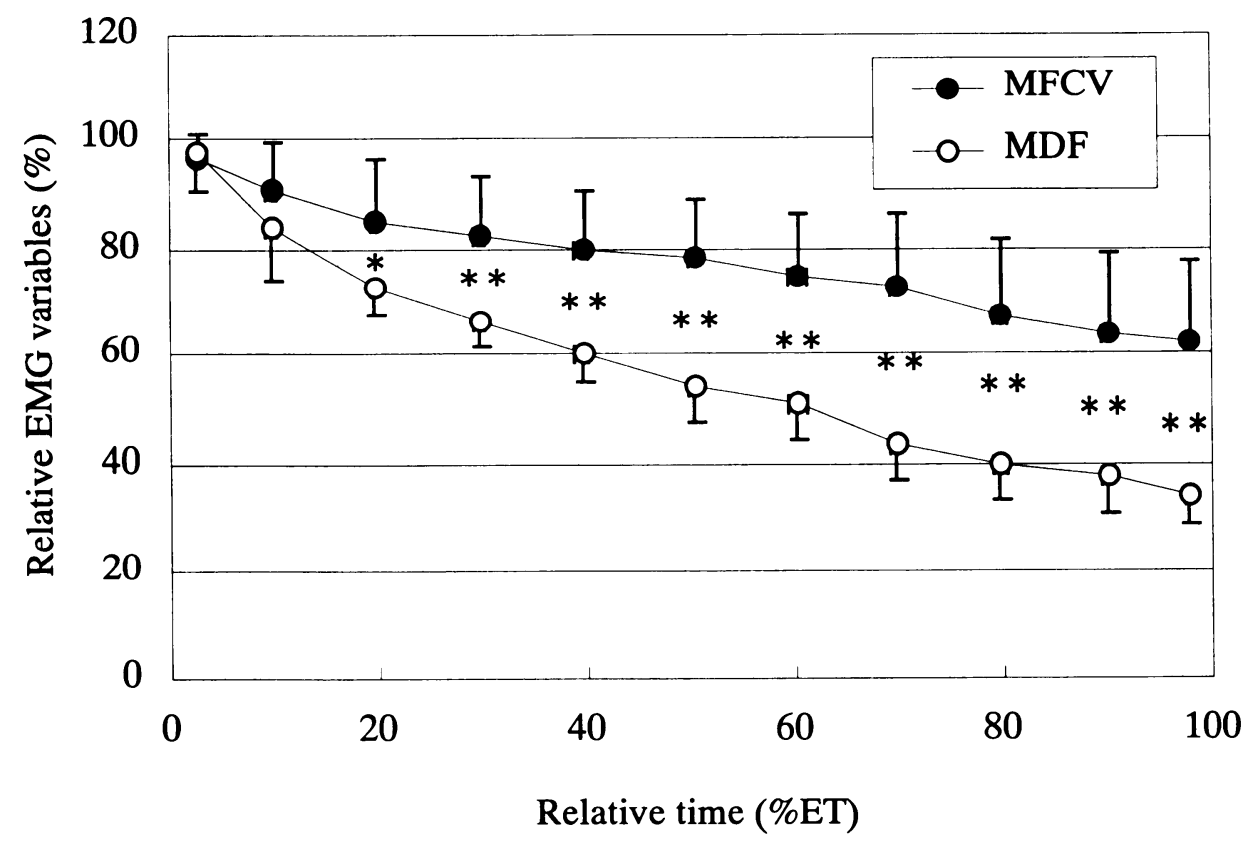

Fig. 4. Changes in the relative value of median frequency (MDF : open cycle) and muscle fiber conduction velocity ( $\mathrm{MFCV}$ : closed cycle) for the voluntary EMG during $60 \%$ MVC fatiguing contractions. MDF and MFCV are normalized by the value at beginning contraction. MDF and MFCV decreased significantly during the contractions $(\mathrm{p}<0.01)$ . Values are mean and $\mathrm{S}$. D. of the 7 subjects. Asterisks show significant differences between the MDF and MFCV $\left({ }^{*}{ }_{p}<0.05:{ }^{*}{ }_{p}<0.01\right)$. 


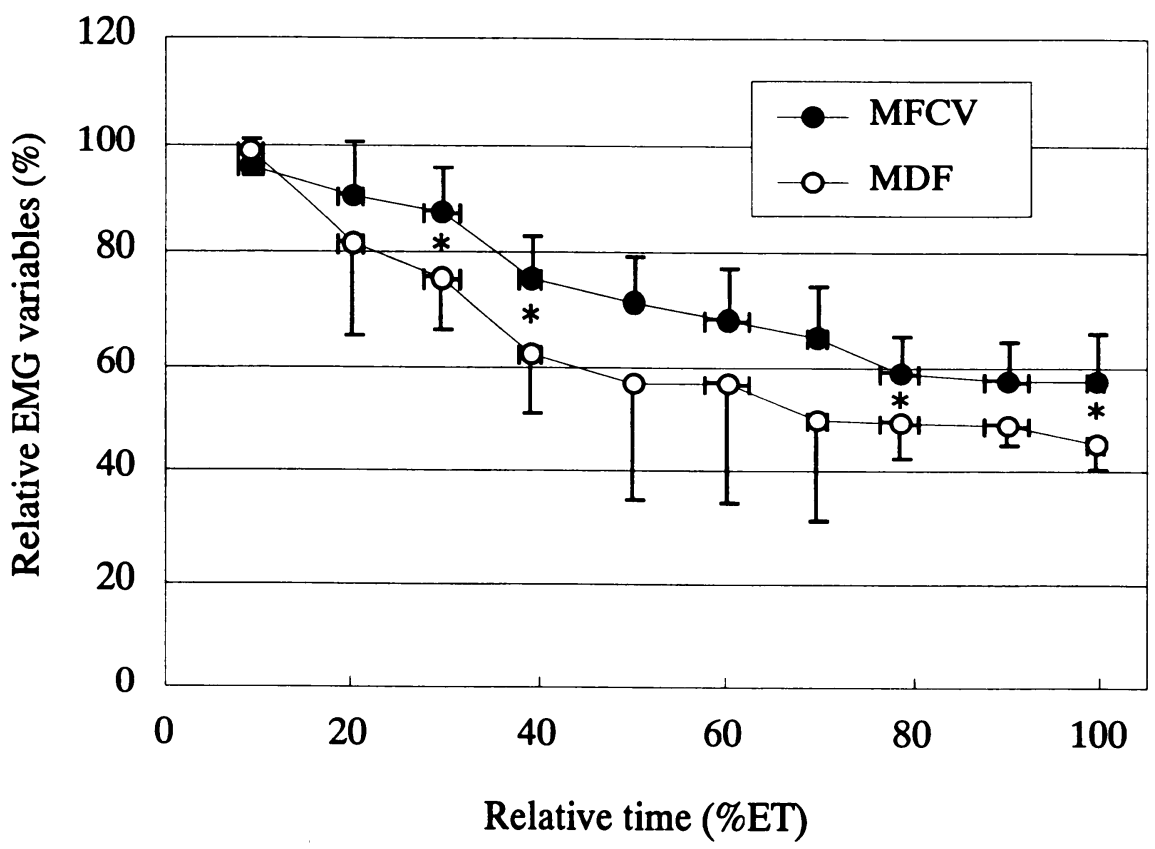

Fig. 5. Changes in the relative value of MDF (open cycle) and MFCV (closed cycle) for the superimposed $\mathrm{M}$-wave during $60 \% \mathrm{MVC}$ fatiguing contractions. MDF and MFCV are normalized by the value at beginning contraction. MDF and MFCV decreased signi. ficantly during the contractions $(\mathrm{p}<0.01)$. Values are mean and $\mathrm{S}$. D. of the 7 sub. jects. Asterisks show significant differences between the MDF and MFCV $\left({ }^{*}<<0.05\right.$; $* * \mathrm{p}<0.01)$.

\section{N. 考察}

\section{A. 計測・解析の妥当性について}

方法で述べたように，表面筋電図変数は等尺性 収縮力が維持出来ている範囲内でもとめた。し たがって, 得られた表面筋電図信号は, 波形解析 における定常性・エルゴード性を満たしてい $ろ^{21,22)}$. そのため, 算出された筋電位信号は筋 の生理学的状態を忠実に反映していると仮定して よい。

本実験では，随意筋電図の解析区間を 0.8 秒に 設定した，筋電困の周波数解析には，2 秒から 3 秒の解析区間が必要であるという報告もある が1), 最近では計算機の性能, 計算法の改良に伴 ってサンプリング周波数を大きくして時間分解能 を向上することにより，0.8秒程度の短い時間で も十分な精度が得られることが知られている23).

一方，これら周波数解析をM波に適用した先行
研究は, 特殊な手法 ${ }^{13,24)}$ を除いてはあまり行わ れていない.なぜならば, M波は潜時が $5 \sim 15 \mathrm{ms,}$ 持続時間が多くとも $50 \mathrm{~ms}$ 以内の極めて短い時 間で出現する電位であり ${ }^{14)}$, 上述した周波数解 析をするうえでの定常性・エルゴード性を仮定で きないからである. 先行研究として, Nagata et al ${ }^{25)}$ は, 前脛骨筋において誘発したM波に高速 フーリエ変換によるスペクトル解析を行い, その 高周波数成分がFT (fast twitch fiber) 線維に, 低 周波数成分がST (slow twitch fiber) 線維に由来す ることを報告しているが，上述した解析区間の問 題までには言及していない. 本研究では, 誘発M 波という極めて持続時間の短い電位に対して, 解 析区間の問題をクリアし, 精度よい周波数解析を 行うために，筋電位信号に白色信号を加える zero-paddingを行った ${ }^{23)}$.この処理により, 精 度のよい周波数解析を行うために十分な解析区間 を得た。 
本研究では10線の小型アレイ多点電極を用いて $9 \mathrm{ch}$ の多点表面 $\mathrm{EMG}$ を尊出し, 得ら机た CC の最も高いチャンネル・ペアから MFCV 算山 した。CCは全体を通じて，ほぼ 0.9 と高い值を 示した。これらの結果は, 多点アレイ電極が筋線 維とほぼ平行に配置しており, 精度よく筋電位変 数が算出できたことを示唆していた。

\section{B. FDI の筋線維伝導速度}

$\mathrm{MFCV}$ は 4〜6 m/s の範井にあり, Sadoyama et al. ${ }^{26)}$ の外側広筋の報告 (平均 $5 \mathrm{~m} / \mathrm{s}$ ) や Masuda et al. ${ }^{20)}$ の上腕二頭筋の報告 (平均 $4 \mathrm{~m} / \mathrm{s}$ ) と比較 するとやや高い值であった。

FDI でMFCV を算出している研究はこれまで みられないために, 先行研究との直接的な比較は できないが，これらの違いは，筋線維組成にみら れる代謝特性や解剖学的構造に加え, 運動単位の 動員動態や発火特性を反映していると考えられる 26ー29)。筋線維組成に関して, FDI はFT 線維と ST 線維をほぼ同等の割合で有しており，上腕二 頭筋や外側広筋とそう大きな違いはない ${ }^{30)}$ 。し かしながら，表面電極を用いて筋電図を導出する 場合，FDI は皮䖉表層に近いために電極のピック アップエリア内に FT 線維が多く仔在し, それら から電位を検出した可能性は高い7). Mito and Sakamoto ${ }^{31)}$ は, 同じく小筋群である咬筋の伝導 速度を調べ，これらがおよそ $10 \sim 12 \mathrm{~m} / \mathrm{s}$ の範囲 にあることを認め, この速い伝導速度が，同じ組 織化学的構造を持つ筋線維が密集する咬筋特有の 構造に依存することを指摘している.

一方, Basjimajian and DeLuca $(1985)^{7}$ は, FDI 等の小筋群では, $50 \% \mathrm{MVC}$ までを動員によって, それ以上を発火頻度で調節するのに対し，无角筋 等の大筋群では $70 \% \mathrm{MVC}$ までを動員で，それ以 上を発火頻度で調節するとを報告している。さら にFDIでは最大発火頻度が 70 pulse/sにも及ぶ こともあることについても言及している。したが って，このような FDI 固有の運動単位の動員· 発射特性が，今回の MFCV の值に影響を与えて いる可能性も考えられる。

電極貼付の際に，神経・筋接合部の近隣に電極
を配置した場合，得られる多点表面筋電位間の時 間差が小さくなり，その值が大きくなることがよ く知られているが29.31)，本研究ではあらかじめ 電極位置についての吟味を十分にしているため に，この影響は小さいと考えられる。

\section{C. 随意収縮持続に伴う随意筋電位の変化}

随意収縮の進行に伴い, 随意筋電位は全ての被 騃者において徐波化し, 疲労の進行を示唆してい た。この徐波化は，1）筋収縮により筋内の血流 が阻害される，2）酸素不足が生じ, 酸化的代謝 を無酸素的代謝へ変化させることにより乳酸が生 成される，3）血流量が少ないためにこの副産物 を洗い出すことが出来ず, 細胞内 $\mathrm{pH}$ が低下する,

4） pHの低下により MFCVが低下する，5） MFCVの低下により運動単位活動電位の shape がゆるやかになる，6）その結果，表面筋電図の 周波数スベクトルが低域にシフトするという連鎖 的事象によって生ずることがわかっている5゙．ま たこれらの機構にみられる末梢性機能低下を補償 するために，新たな運動単位の動員や発火頻度の 增大や同期化等が生じ，こ机らがスペクトルの低 脚波数成分に影響を与えるという報告もなされて いる ${ }^{13.32)}$.

これに対し，随意筋電位の振幅は一貫した変化 を示さなかった(四 3 )。表面筋電図の振幅は波労 に伴って漸増的に増加することがよく知られてい るが，これらは上述の中枢補償機構によるという 考え方が主流である4.33.34!．FDIにおいてこの 補償機構が小さいことは，主として上述した FDI 固有の連動単位の動員抢よび発火特性に依存して いると考えられる。また，下腿三頭筋や大腿汇頭 筋のような大筋群に扔いては疲労に伴う運動単位 の活動父代や，あるいは他の筋からの活動の参入 がクロストークとして振幅を増大させている可能

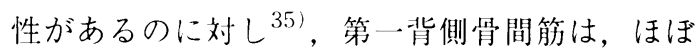
単一で示指の外転力を維持しているために、これ らの関与がないことも原因のひとつとしてあげら れる。 


\section{D. 疲労に伴う重畳M波の变化}

疲労進行に伴い, 重畳M波の振幅は低下し，持 続時間は延長した(図 3 )。これらの報告も先行研 究と同様であった ${ }^{13,36)}$. 収縮持続に伴う安静時 の誘発M波の振幅低下は，主として神経・筋接合 部に扔ける化学物質の伝達遮断に起因することが 報告されているが15)，これらの機構が，今回計 測した随意筋電位に重畳するM波に単純に適用で きるかどうかにについては，今後検討の余地があ ると思われる。

この重疊M波は，電気刺激により誘発された電 位であり，その持続時間の延長は，笳線維膜を伝 搬するインパルスの伝導速度低下によって引き起 こされたと考えられる。安静時の誘発M波の持続 時間の延長の機構については, ラットの摘出筋を

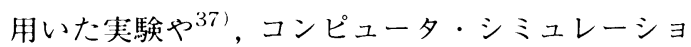
ンを用いた工学的手法により検証されており ${ }^{38)}$, 重畳M波についても，同様の機構によって生ずる ことがわかっている ${ }^{24)}$.これら収縮持続に伴う 随意筋電四，および重畳 $\mathrm{M}$ 波の变化は全て先行研 究と同様であり，本実験において $60 \% \mathrm{MVC}$ の持 続的な筋収縮によって疲労が進行していたことを 示唆していた。

\section{E. 重睤M波生成機構を考慮した徐波化機構}

この表面筋電四変化パターンは MDF や MFCV により定量できる。四 4 に示すように，随意筋電 位の MDFと MFCV は疲労進行に伴って単調減 少を示し，その変化幅はMFCVに比べMDFで 大きかった。これらの結果は先行研究と同様であ った ${ }^{9)}$.

今回，この随意筋電位にみられる徐波化機構， とりわけ MDF 低下を生じさせる MFCV 以外の 機構を検討するために，重睍M波解析を用いた。 M波は神経幹を電気刺激することによって得られ る複合活動電位である。したがって，脊髄やそれ 以上の上位レベルの情報は含まれない，上述した ように，FDIにおいて 60\%MVCでは，ほほ全て の運動単位が動員されている，従って，この重畳 M波を調べることにより, 疲労試技に動員されて いた全ての運動単位の末梢レベルでの生理的状態
を検出できる.

この重畳M波について MDF と MFCV の関係 を調べたところ，随意筋電位と同様にその変化幅 はMFCV と比較してMDFでより大きかった(図 5 )。これらは，これまで報告されていない新た な知見である。上記の重㓯M波出現機構より，こ の MDFの低下に及ぼす運動単位の動員や発射特 性の変化等の中枢性の要因は無視できる。しがた って，これら重畳M波の徐波化には，MFCV 以外 の未梢性要因のみが関与していると考えることが できる.

これら末梢性機構解明に焦点をあてて, 運動単 位活動電位の shapeに影響を及ぼす要因を調べ た研究として, Brody et al. ${ }^{37)}$ は, ラットの横隔 膜の筋標本を電気刺激し, $\mathrm{pH}$ および頻発刺激疲 労がM波の shapeに及ほす影響を調べ, 疲労によ る表面筋電四中央周波数の変化が，運動単位活動 電位の fundamental shape の変化(歪み)によって 生ずることを示している。そして彼らは，この fundamental shape の歪みに対して, 筋線維膜の $\mathrm{Na}^{-}$と $\mathrm{K}^{+}$勾配(筋鞘に扔ける脱分極と再分極の 速度)の変化,つまり筋線維膜におけるイオンチャ ンネルの拡がりが関与していることを明らかにし た。これらは，同様の動物実験によって細胞膜レ ベルに扔いても証明されている39.40).

ヒトを対象とした実験では, Kiryu et al. ${ }^{13)}$ は 前脛骨筋を対象として随意収縮中に電気刺激を施 し，随意筋電位の平均周波数と重畳 $\mathrm{M}$ 波の瞬時周 波数の相関関係を検討し，これらの相関関係の变 化が重㽪M波の陽性ピーク，陰性ピーク毎に異な ることを見出し, 疲労進行に伴う表面筋電図の徐 波化に対して運動単位活動電位の shape の变化 が関与していること, shapeの变化に対して筋線 維の脱分極ゾーンの延長が関与していることを報 告している. Yamada et al. (2001) ${ }^{36)}$ は第一背側 出間筋を対象として同様の報告をしている。これ らに関して, Merletti et al. (1999) ${ }^{38)}$ は数学モデ ルを用いて，ヒトの前脛骨筋より導出したM波の スペクトルパラメータに対して, 筋線維伝導速度 と脱分極ゾーンの搪がりが関与することを証明し ている. 
これらの報告に今回の知見をふまえると, 表面 筋電図の徐波化を生じさせる末梢性要因として, 筋線維膜のイオン勾配の变化に起因する脱分極 ゾーンの空間的な拡がりが最も有力であると考え られる。この脱分極ゾーンの搪がりは, 随意筋電
位(あるいはM波)を構成する個々の活動電位の shape を決定する要因であり, pH 低下による伝 搬障害によって全ての活動電位に共通してみられ る伝導速度低下とは異なった機構であることが報 告されている37,38,41).

A

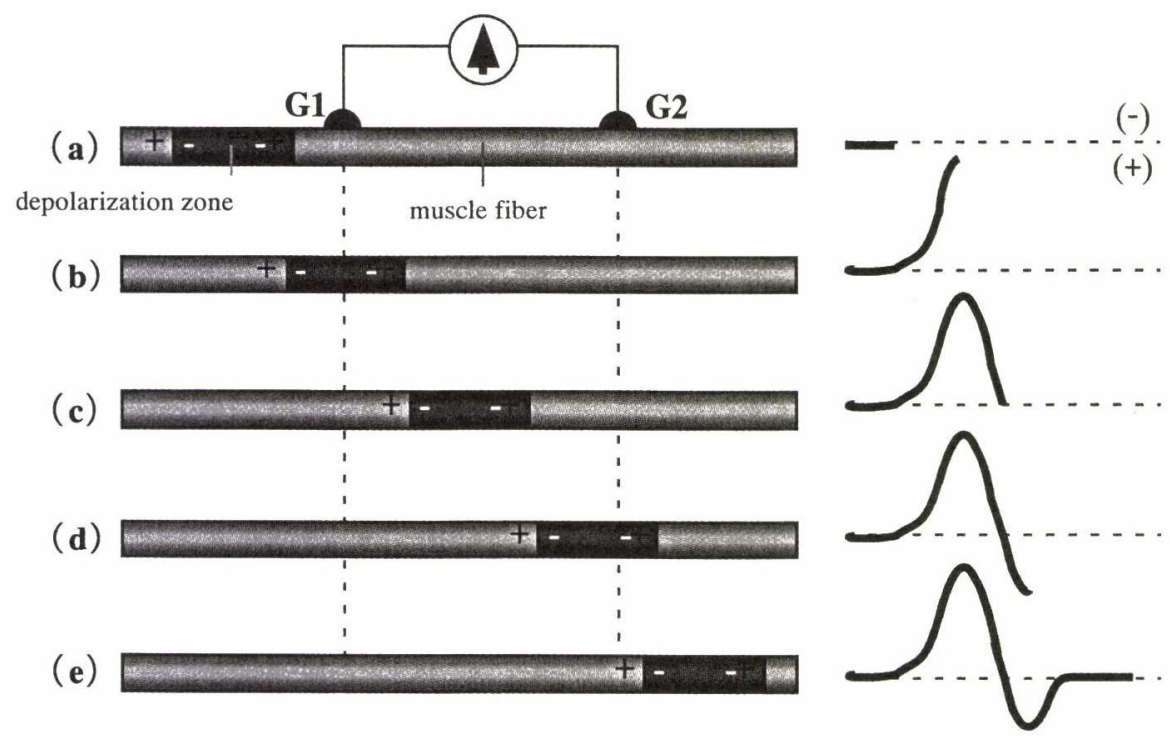

B

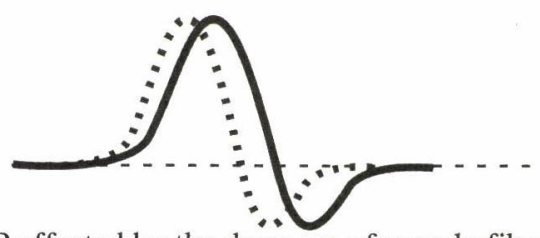

(1) MUAP affected by the decrease of muscle fiber conduction velocity

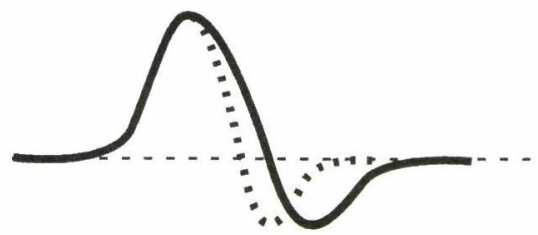

(2) MUAP affected by the elongation of depolarization zone in muscle fiber

Fig. 6. Mechanism for slowing surface electromyography during fatiguing contraction. Schematic illustration for recording of motor unit action potential detected by using surface electrode (A). Schematic illustration for changes of shape in the motor unit action potential (B). 
困 6 は，一般的な活動電位の発生機構 ${ }^{42)}$ を とに，運動単位活動電位の shape に影響を与え る因子を模式化したものである。Aは，表面電極 により得られた運動単位活動電位の発生機序につ いて示している。この図では，(a)から(e)にかけ て，筋線維の中を脱分極ゾーンが伝導していく様 子を示している。（a），(c)，(e)では，基準電極 G2 に対して活動電極 G1 は等電位になっている が，(b)では陰性，（d）では陽性となるために， 結果として二相性の活動電位が得られる。Bは, Aで発生した運動単位活動電位の変化機序につい て示している，従来の報告通り，筋線維内におけ る脱分極ゾーンの伝導が遅くなると, 表面電極に よって記録された二相性の活動電位が，（1）のよ うに単調に，かつ均等に間延びする ${ }^{4-6)}$.これ に対し，脱分極ゾーンが空間的に拡がると，(2) のように陰性抢よび陽性ピークから基線への戻り が遅れ，歪みが生ずる13.36 -38)。この四に示す ように，筋線維膜のイオン勾配の変化に起因する 脱分極ゾーンの空間的な拡がりが, 個々の運動単 位活動電位の shape を変化させる。そして, pH 低下に起因する伝導障害による筋線維伝導速度の 低下にみられる時間的な搪がりが，運動単位活動 電位の shape の全体的間延びを生じさせる。こ れらが複合した結果として，伝導速度の低下を上 回る周波数低下が生じたと考えられる。

本実験の結果から，随意収縮の持続に伴う表面 筋電図の徐波化に対して, 筋線維伝導速度以外の 末梢性要因が関与していることが明らかとなっ た。そして，その末梢性要因のひとつとして，膜 イオン勾配の変化に起因する筋線維膜の脱分極 ゾーンの空間的拡がりの関与が提案された。こら らの機構については, 今後コンピュータシミュ レーションやさらなる動物実験による検証が必要 であると思われる。

\section{V. ま と め}

本研究では，第一背側骨間筋(FDI)を対象に, 最大随意収縮力の $60 \%$ 強度で疲労困傋までの等尺 性示指外転を行わせ，随意筋電位と，電気刺激 によってそれに重畳して得られる誘発M波につい
て，筋線維伝導速度 $(\mathrm{MFCV})$ と中央周波数 $(\mathrm{MDF})$ の関係を調べ，随意収縮による瘦学進行に伴う表 面筋電図の徐波化機構について検討した，得られ た結果は以下の通りである。

1） $60 \% \mathrm{MVC}$ 時の FDIにおける随意筋電図よ

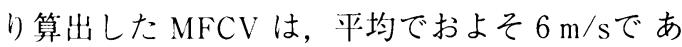
った。

2） $60 \% \mathrm{MVC}$ の持続的収縮に伴い, FDI から 導出した随意による表面筋電四は全ての被験者に ついて徐波化し, 疲労の進行を示唆していた。

3）疲労進行に伴い, 随意筋電位に重畳する $\mathrm{M}$ 波の振幅は低卜し，持続時間は延長した。

4）疲労進行に伴い, 随意筋電位の MDF と MFCV は有意に低下し $(\mathrm{p}<0.01)$ ，その変化幅は， MDFにおいて有意に大きかった $(\mathrm{p}<0.01)$.

5）疲労進行に伴い，末梢性指標である重畳M 波の MDF と MFCV は有意に低下し $(\mathrm{p}<0.01)$, その変化幅は，MDFにおいて有意に大きかった $(\mathrm{p}<0.05)$.

これらの結果より，随意筋電四の徐波化に対 し，MFCV とそれ以外の末梢性要因が関与する ことが明らかとなった。また，その末梢性要因の ひとつとして, 筋線維膜のイオン勾配の変化に起 因する脱分極ゾーンの空間的な拡がりが関与して いる可能性が推察された。

\section{(受理日 平成14年10月22日)}

\section{参考文 献}

1）小木和孝, 袴田 忠. 筋疲労時の表面筋電図の周 波数解析. 労働科学. (1962) $38: 519-528$.

2) Okada, M. Some properties of the 'Global' elec tromyogram in man as revealed by frequency analy. sis. J. Fac. Sci. Univ. Tokyo (1971) 4:61-80.

3) Stulen, F.B. and De Luca, C.J. Muscle fatigue moni tor: A noninvasive device for observing localized muscular fatigue. IEEE. Trans. Biomed. Eng. (1982) 29 : 760-768.

4) DeLuca C. J. Myoelectrical manifestations of local. ized muscular fatigue in humans. CRC Crit. Rev. .Biomed. Eng. (1984) $11: 251-279$.

5) Lindström, L., Magnusson, R. and Petersén, I. Mus. cular fatigue and action potential conduction velocity changes studied with frequency analysis of EMG signals. Electromyography. (1970) $10: 341-$ 356, 1970. 
6) Sadoyama, T., Masuda, T. and Miyano, H. Relation ships between muscle fibre conduction velocity and frequency parameters of surface EMG during sus tained contraction. Eur. J. Appl. Physiol. (1983) 51 247-256.

7) Basmajian. J.B. and De Luca, C.J. Muscles Alive. 5th. Ed.Williams \& Wilkins. 1985.

8) Krogh-Lund, C. and Jorgensen, K. Myo-electric fatigue manifestations revisited: power spectrum, con. duction velocity, and amplitude of human elbow fle. xor muscles during isolated and repetitive endurance contractions at $30 \%$ maximal voluntary contraction. Eur. J. Appl. Physiol. Occup. Physiol. (1993) $66: 161-173$.

9) Masuda, K., Masuda, T., Sadoyama, T., Inaki, M. and Katsuta. S. Changes in surface EMG parameters during static and dynamic fatiguing contractions. J. Electromyogr. Kinesiol. (1999) $9: 39-46$.

10）佐藤方彦. 双極表面誘導筋電汹の周波数成分. 人 類学雑誌. (1964) 72 : 92-106.

11) Kadefors, R., Kaiser, E. and Petersén, I. Dynamic spectrum analysis of myo-potentials with special reference to muscle fatigue. Electromyography. (1968) $8: 39-74$.

12) Mills, K.R. Power spectral analysis of electromyogram and compound muscle action potential during muscle fatigue and recovery. J. Physiol. (1982) 326 : 401-409.

13) Kiryu, T., Morishita, M., Yamada, H. and Okada, M. A muscular fatigue index based on the relationships between superimposed $\mathrm{M}$ wave and preceding background activity. IEEE. Trans. Biomed. Eng. (1998) 45 : 1194-1204.

14）藤原哲司．筋電四マニュアル．金芳堂．1984

15）小谷山伴与志，河合辰夫，古林俊晃. 筋波学の神 経生理学的機序. 千葉大学教育学部研究紀要. (1994) $42:$ :53-72.

16) Masuda T., Miyano, H. and Sadoyama. T. The propagation of motor unit action potential and the location of neuromuscular junction investigated by sur. face electrode arrays. Electroenceph. Clin. Neurophysiol. (1982) $55:$ 594-597.

17) Merletti, R., Fiorito, A., Lo Conte, L. R. and Cisari, C. Repeatability of electrically evoked EMG signals in the human vastus medialis muscle. Muscle Nerve. (1998) $21: 184-193$.

18) Masuda, T. Interface device which displays the propagation of motor unit action potentials on a television screen. Med. \& Biol. Eng. \& Comput. (1985) $23: 493-495$.

19) Merletti, R., Sabbahi, M. A. and De Luca. C. J. Median frequency of the myoelectric signal. Effects of muscle ischemia and cooling. Eur. J. Appl. Physiol. Occup. Physiol. (1984) 52 : 258-265.

20) Masuda, T., Sadoyama, T. and Shiraishi, M. Depend. ence of average muscle fiber conduction velocity on voluntary contraction force. J. Electromyogr. Kinesiol. (1996) 6 : 267-276.

21) 献茂夫. 科学計測のための波形デー夕処理. CQ 出 版社. 1986.

22）鈴木良次, 佐藤俊輔, 池田研一, 吉川昭. 生体信 号一計測と解析の実際一。コロナ社, 1989.

23）増田正。一口伝 主面筋電四篇一ただいま処理 中の卷。バイオメカニズム学会誌 (2001) $25: 88^{-}$ 92.

24) Kiryu, T., Saitoh, Y. and Ishioka, K. A muscle fati. gue index based on the relationship between preceding background activity and myotatic reflex re. sponse (MRR). IEEE. Trans. Biomed. (1992) 39 : 105-111.

25) Nagata, A. and Christianson, J. C. M-wave modula tion at relative levels of maximal voluntary contrac. tion. Eur. J. Appl. Physiol. Occup. Physiol. (1995) $71: 77-86$.

26) Sadoyama, T., Masuda, T., Miyata, II. and Katsuta, $S$. Fibre conduction velocity and fibre composition in human vastus lateralis. Eur. J. Appl. Physiol. (1988) $57: 767-771$.

27) Masuda. T. and De Luca, C. J. Recruitment threshold and muscle fiber conduction velocity of single motor units. J. Electromyogr. Kinesiol. (1991) 1:116-123.

28）増旧 正. 筋電汹による筋闪の機能と構造の推定. バイオメカニズム学会誌 (1991) $15: 132-141$.

29) Yamada, H., Masuda, M. and Okada. M. Age-related EMG variables during maximum voluntary contrac. tion. Perceptual and Motor Skills. (2002) $95: 10$ 11.

30) Zijdewind, I. and hernell, D. Fatigue associated EMG behavior of the first dorsal interosseous and adductor pollicis muscles in different groups of sub. jects. Muscle Nerve. (1994) $17:$ 1044-1054.

31) Mito, $K$. and Sakamoto, K. Distribution of muscle fiber conduction velocity of m. masseter during voluntary isometric contraction. Electromyogr. Clin. Neurophysiol. (2000) $40: 275-285$.

32) Kranz. H., Williams, A. M., Cassell, J., Caddy, D. J. and Silberstein, R. B. Factors determining the fre. quency content of the electromyogram. J. Appl. Phy siol. (1983) $55: 392-399$.

33) Maton, B. Frequency analysis of surface electromyo. gram during sustained isometric contractions. Eur. J. Appl. Physiol. (1981) 43 : 173-182.

34）森谷敏夫. 筋闪と疲労.体育の科学. (1992) 42 : 335341.

35) De Luca. C.J. The use of surface electromyography in biomechanics. J. Appl. Biomechanics. (1997) 13 : $135-163$.

36) Yamada, H., Okada, M. and Kiryu, T. Development of muscle fatigue assessed by using superposition of evoked and volitional myoelectric potentials. Perceptual and Motor Skills. (2001) $93: 3-10$.

37) Brody, L.R., Pollock, S.H., Roy, S.H., De Luca, C.J. 
and Bartolome. C. pH-induced effects on median frequency and conduction velocity of the myoelectric signal. J. Appl. Physiol. (1991) $71:$ 1878-1885.

38) Merletti, R., Roy, S. H., Kupa, E., Roatta, S. and Granata, A. Modeling of surface myoelectric signals Part II: Model-based signal interpretation. IEEE. Trans. Biomed. Eng. (1999) $46: 821-829$.

39) Dimitrova, N. Influence of the length of the depolarization in the extracellular potential field of a single unmyelinated nerve fibre. Electromyogr. Clin. Neurophysiol. (1993) $13: 547$.
40) Edward, M. B. and Fitts, R. H. Effects of depolarization and low intracellular pH on charge movement currents of frog skeletal muscle fibers. J. Appl. Phy. siol. (2001) $90: 228-234$.

41) Chisari, C.. D'alessandro, C..Manca, M. L. and Rossi, B. Sarcolemmal excitability in myotonic dystrophy: Assessment through surface EMG. Muscle Nerve (1998) $21: 543-546$.

42）Kimura, J. 神経 - 筋疾患の電気診断学. 西川書店, 1989. 